\title{
Artikel
}

\section{De rol van alternatieve handhaving in het mededingingstoezicht}

\author{
Eva Lachnit*
}

In deze bijdrage worden enkele alternatieve handhavingsinstrumenten geanalyseerd zoals zij gebruikt worden door de Nederlandse Autoriteit Consument en Markt (ACM), de Britse Competition and Markets Authority (CMA) en de Franse Autorité de la Concurrence (de Autorité). Echter, hierbij ligt de focus niet op de individuele, juridische analyse van ieder handhavingsinstrument, maar op de relatie tussen handhavingsinstrumenten, onderliggende strategie, en toezichthouder. Het uiteindelijke doel van deze bijdrage is om te illustreren wat de gevolgen kunnen zijn van een brede toepassing van alternatieve handhavingsinstrumenten vanuit het perspectief van toezicht. Hierbij zullen er, met name in de concluderende paragrafen, conclusies worden getrokken die bruikbaar zijn voor het toepassen van alternatieve handhaving buiten het mededingingstoezicht.

\section{Inleiding}

Bij het houden van toezicht op de marktwerking maken mededingingsautoriteiten gebruik van verschillende handhavingsinstrumenten. Hoewel zij erom bekend staan vaak hoge bestuurlijke boetes op te leggen, maken mededingingsautoriteiten vaak ook gebruik van alternatieve handhavingsinstrumenten. Maar hoe verhouden deze alternatieve instrumenten zich tot de andere instrumenten? Wat valt er over de toezichtstijl van de mededingingsautoriteit te zeggen als er gekeken wordt

\footnotetext{
Mr. dr. E.S. Lachnit is universitair docent Economisch Publiekrecht bij de Universiteit Utrecht. Zij promoveerde in september op het proefschrift Alternative Enforcement of Competition Law en doet onderzoek en advisering op het gebied van toezicht- en handhavingsstrategieën van toezichthouders in brede zin.
}

naar de samenhang tussen de verschillende (reguliere én alternatieve) instrumenten? En wat is de impact van het gebruik van alternatieve instrumenten voor een toezichthouder zelf, en zijn positie in het toezichtlandschap? Met de handhavingspraktijk van drie verschillende nationale mededingingsautoriteiten als uitgangspunt probeert deze bijdrage een antwoord op deze vragen te vinden. ${ }^{1}$

Dat kartelafspraken schadelijk zijn voor de consumentenwelvaart is bekend. Dat mededingingsautoriteiten hoge boetes opleggen aan karteldeelnemers is eveneens bekend. Recent nog legde de Europese Commissie een boete van $€ 485$ miljoen op aan een drietal banken voor het maken van prijsafspraken over rentederivaten. ${ }^{2}$ Dat mededingingsautoriteiten naast deze spectaculaire bestuurlijke boetes ook veel andere handhavingsinstrumenten toepassen, is minder bekend. Echter, de meeste autoriteiten zijn net zo actief - zo niet actiever - op het gebied van voorlichting, overleg, beïnloeding en preventie, waartoe zij verschillende instrumenten tot hun beschikking hebben.

Het opleggen van een bestuurlijke boete (of het geven van een bindende aanwijzing, of het opleggen van een last onder dwangsom) door middel van een procedure op tegenspraak kan worden gekarakteriseerd als een formele interventie met een afschrikwekkend, reactief en zaaksgebonden karakter, gebaseerd op een verticale relatie tussen de ondernemingen en de mededingingsautoriteiten. Alternatieve handhavingsinstrumenten daarente-

1. Deze bijdrage is gebaseerd op het proefschrift van de auteur, waarin deze vragen - samen met een uitgebreide juridische analyse van de verschillende handhavingsinstrumenten - centraal staan. Zie E.S. Lachnit, Alternative Enforcement of Competition Law, Den Haag: Eleven International Publishing 2016.

2. Zie het persbericht van de Europese Commissie van december 2016 op <http://europa.eu/rapid/press-release_IP-16-4304_en.htm>. 
gen, zoals een schikking, een informele anwijzing of een marktstudie, kenmerken zich door één of meer tegenovergestelden van deze eigenschappen: zij zijn vaker informeel, meer horizontaal, compliance-gericht, proactief, breed inzetbaar of een combinatie hiervan. ${ }^{3}$ Alternatieve handhavingsinstrumenten zijn derhalve geen 'vaste' categorie instrumenten, maar meer een benaming voor het type handhavingsinstrument dat op een of andere wijze afwijkt van de meer klassieke (of 'reguliere') instrumenten als bestuurlijke boete, last onder dwangsom of bindende aanwijzing.

In deze bijdrage worden enkele alternatieve handhavingsinstrumenten geanalyseerd zoals zij gebruikt worden door de Nederlandse Autoriteit Consument en Markt (ACM), de Britse Competition and Markets Authority (CMA) en de Franse Autorité de la Concurrence (de Autorité). ${ }^{4}$ Hierbij ligt de focus echter niet op de individuele, juridische analyse van ieder handhavingsinstrument, maar meer op de relatie tussen handhavingsinstrumenten, onderliggende strategie en toezichthouder. Zo wordt er aandacht besteed aan de verhouding tussen alternatieve en reguliere handhavingsinstrumenten, aan de plaats van alternatieve handhavingsinstrumenten binnen de toezichts- en handhavingsstrategieën van de drie toezichthouders, en aan de impact van het gebruik van alternatieve handhavingsinstrumenten op de toezichthouder zelf en zijn positie in het toezichtlandschap.

Het gaat in deze bijdrage om een (korte) internationale vergelijking van handhavingsinstrumenten en toezichthouders. Om een en ander in de juiste nationaalrechtelijke context te kunnen plaatsen, volgt er derhalve eerst een korte beschrijving van de Nederlandse, de Britse en de Franse mededingingsautoriteit. Hierbij is er aandacht voor institutional design, voor verschillen in missie en strategie en voor enkele juridische bijzonderheden die van belang zijn bij het toepassen van alternatieve handhavingsinstrumenten (zie Nationale mededingingsautoriteiten nader bekeken). $\mathrm{Na}$ deze contextschets volgt een analyse van een viertal alternatieve handhavingsinstrumenten vanuit toezichtsperspectief, waarbij er met name aandacht is voor de handhavingdoelen die met deze instrumenten worden nagestreefd en de spanning die dit kan opleveren (zie Alternatieve handhavingsinstrumenten). Op basis van deze analyse - waarbij ook de nationale

3. Dit onderscheid wordt gemaakt om alternatieve handhavingsinstrumenten als categorie te kunnen onderscheiden van de bestuurlijke boete, bindende aanwijzing en last onder dwangsom. Alternatieve handhavingsinstrumenten onderscheiden zich als alternatief door een van deze alternatieve kenmerken te bezitten (bijvoorbeeld wel formeel, maar op basis van overleg), of een combinatie van verschillende kenmerken. Dit impliceert niet dat alternatieve handhavingsinstrumenten in de regel minder gebruikt worden (dit hoeft niet bij alle toezichthouders het geval te zijn). Zie in dit verband uitgebreider het proefschrift van auteur, Lachnit 2016, hfdst. 1

4. Deze afbakening is gebaseerd op de afbakening in Lachnit 2016, maar is ook voor deze bijdrage erg interessant, omdat dit het verschil tussen de verschillende autoriteiten duidelijk naar voren laat komen. Dit laat zien, zoals ook hieronder zal worden geconcludeerd, dat het ontwerp en de toepassing van alternatieve handhavingsinstrumenten erg afhankelijk is van de juridische context en het karakter van de toezichthouder die ze gebruikt. praktijk van ACM, de CMA en de Autorité kort wordt angestipt - worden er enkele conclusies getrokken met betrekking tot het handhavingsbeleid van de nationale autoriteiten en de plaats van alternatieve handhaving daarbinnen (zie Typering praktijk nationale autoriteiten). Tot slot wordt alternatieve handhaving als zodanig in een bredere context geplaatst en volgen enkele observaties dienaangaande (zie Alternatieve handhaving in bredere context).

Het uiteindelijke doel van deze bijdrage is om te illustreren wat de gevolgen kunnen zijn van een brede toepassing van alternatieve handhavingsinstrumenten vanuit het perspectief van toezicht. Hierbij zullen er, met name in de concluderende paragrafen, conclusies worden getrokken die bruikbaar zijn voor het toepassen van alternatieve handhaving buiten het mededingingstoezicht.

\section{Nationale mededingings- autoriteiten nader bekeken}

Alvorens dieper in te gaan op de het gebruik van alternatieve handhavingsinstrumenten is het relevant om te bekijken hoe de verschillende mededingingsautoriteiten functioneren. Dit helpt niet alleen om de verschillende instrumenten in de juiste context te plaatsen, maar ook om dwarsverbanden te leggen naar andere terreinen van toezicht. De Nederlandse ACM, de Britse CMA en de Franse Autorité verschillen namelijk van institutionele organisatie, waardoor er bij het bekijken van deze autoriteiten inspiratie kan worden geput voor verschillende andere toezichthouders. Bij deze korte bespreking wordt er kort aandacht besteed aan de vormgeving van de toezichthouder als agency, aan de missie en strategie (inclusief handhavingsinstrumenten) en aan enkele juridische bijzonderheden in het besluitvormingsproces die relevant zijn bij de bespreking van alternatieve handhavingsinstrumenten hierna.

\section{Autoriteit Consument en Markt (Nederland)} De Autoriteit Consument en Markt is in 2013 opgericht na een fusie van de Nederlandse Mededingingsautoriteit, de Onafhankelijke Post en Telecomautoriteit en de Consumentenautoriteit. ${ }^{5}$ Omdat ACM verschillende functies vervult, kan het getypeerd worden als een combinatie van een mededingingsautoriteit, consumentenautoriteit en multisector toezichthouder, wat wereldwijd gezien vrij uniek is. ${ }^{6}$ ACM is als zelfstandig bestuursorgaan operationeel onafhankelijk, maar legt verantwoor-

5. Wet van 28 februari 2013, houdende regels omtrent de instelling van de Autoriteit Consument en Markt, Stb. 2013, 102 (hierna: Instellingswet Autoriteit Consument \& Markt).

6. Alleen de Australische ACCC heeft een vergelijkbaar takenpakket. Zie uitgebreider over deze typeringen: A.T. Ottow, 'Erosion or Innovation? The institutional design of competition agencies - a Dutch case study', Journal of Antitrust Enforcement 2014, p. 1-19. 
ding af aan de minister van Economische Zaken. ${ }^{7}$ Deze verantwoordingsplicht strekt zich ook uit tot de balans (het budget), waarbij als inkomen de boete-inkomsten worden meegenomen. ${ }^{8}$ De minister kan zich in beginsel niet mengen in individuele zaken, tenzij ACM ultra vires handelt. ${ }^{9}$ Daarnaast kan de minister beleidsregels opstellen die de bevoegdheden van ACM op basis van de toepasselijke wetten nader invullen. ${ }^{10}$

'De ACM bevordert kansen en keuzes voor bedrijven en consumenten.' ${ }^{11}$ Dit is de missie die ACM-breed uitgedragen wordt en waarbij de consument centraal staat. ACM doet dit, onder andere, door toezicht te houden op de naleving van de Mededingingswet. In enge zin geeft de Mededingingswet ACM de bevoegdheid om bij constatering van een inbreuk een bestuurlijke boete of een last onder dwangsom op te leggen. ${ }^{12}$ ACM heeft echter een breed genoeg mandaat om ook andere toezichtsactiviteiten te ontplooien, zoals het stimuleren van naleving door middel van voorlichting, het informeel wijzen op rechten en plichten van bedrijven en het onderzoeken en in kaart brengen van marktproblemen. Met betrekking tot die laatste activiteit heeft ACM zelfs verregaande bevoegdheden gekregen ten behoeve van het vergaren van informatie. ${ }^{13}$ ACM heeft derhalve de beschikking over een scala aan handhavingsinstrumenten, variërend van licht tot zwaar, en van informeel tot formeel. Om de keuze voor het juiste handhavingsinstrument op een uniforme manier te kunnen bepalen maakt ACM gebruik van een expliciete onderliggende toezichtstrategie: het probleemoplossend toezicht. ${ }^{14}$

Zoals veel markttoezichthouders kent ook ACM het 'alles-in-een-hand-stelsel', hetgeen inhoudt dat ACM verantwoordelijk is voor opsporing, onderzoek en beboeting van overtredingen. ${ }^{15}$ Wel maakt ACM hierbij gebruik van een functiescheiding, waardoor de personen verantwoordelijk voor het onderzoek niet meer betrokken zijn bij het opleggen van de boete (de Chinese

7. Zie Kaderwet Zelfstandige Bestuursorganen, maar uitgebreider ook B.M.J. van der Meulen, 'Een erg zelfstandig bestuursorgaan', M\&M 2012/4, p. 139-140.

8. Art. 18 Kaderwet Zelfstandige Bestuursorganen.

9. Dit blijkt uit art. 10 Instellingswet Autoriteit Consument \& Markt (ultra vires), maar ook uit art. 11 Instellingswet Autoriteit Consument \& Markt (verwaarlozing van taken)

10. Zie art. 1B (par. 3-6), 6B, 7 en 12M Stroomlijningswet 2014.

11. Missie ACM online, zie <www.acm.nl/nl/organisatie/missie-visiestrategie/onze-missie/>.

12. Dit is geen uitputtende weergave van de bevoegdheden van $A C M$, maar wel een illustratie van de meer 'klassieke' handhavingsinstrumenten die de Mededingingswet bevat.

13. Art. $6 \mathrm{~b}$ Stroomlijningswet jo. art. 2 leden 2 en 4 Stroomlijningswet.

14. Strategie Autoriteit Consument en Markt, 20 september 2013. Het basisconcept voor deze toezichtstrategie is simpel: 'pick important problems and fix them'. Probleemoplossend toezicht gaat uit van de volle breedte van het instrumentarium, en biedt een stappenplan om deze op een effectieve manier te gebruiken. Zie uitgebreider M.K. Sparrow, The Regulatory Craft, Brookings Institutions Press 2000.

15. Zie voor kritiek B.H.J. Braeken, 'CBb stelt grenzen aan alles-in-één-hand stelsel', M\&M 2011/6. Dit is een annotatie bij CBb 30 augustus 2011, ECLI:NL:CBB:2011:BR6737 (ETB de Vos).
Wall). ${ }^{16}$ Deze functiescheiding vormt een waarborg voor onafhankelijke en onpartijdige besluitvorming. Bij ACM staat deze spreekwoordelijke muur tussen de Directie Mededinging (verantwoordelijk voor het onderzoek) en de Directie Juridische Zaken (verantwoordelijk voor de beboeting). Tot slot is het waard te vermelden dat ACM onder de Algemene wet bestuursrecht een bezwaarprocedure hanteert bij formele besluiten. ${ }^{17}$ Hoewel dit onder Nederlands recht niet bijzonder is, kennen veel mededingingsautoriteiten van andere landen een dergelijke procedure tot bestuurlijke heroverweging niet.

\section{Competition and Markets Authority (Verenigd Koninkrijk)}

De Competition and Markets Authority in haar huidige vorm is ontstaan in 2014, als samenvoeging van het Britse Office of Fair Trading en de Competition Commission. De CMA is een toezichthouder met een duale functie; zij bevordert concurrentie op de markt en behartigt - tot op zekere hoogte - consumentenbelangen. De missie van de CMA is dan ook: 'promote competition, both within and outside the United Kingdom, for the benefit of consumers'. ${ }^{18}$ Anders dan de Nederlandse ACM houdt de CMA zich niet bezig met toezicht op gereguleerde sectoren; daarvoor werkt zij samen met de verschillende sectorspecifieke toezichthouders.

De CMA is een zogenoemd niet-ministerieel departement. Dit houdt in dat de CMA operationele vrijheid geniet en voor haar functioneren verantwoording schuldig is aan het Parlement - en niet aan, bijvoorbeeld, het ministerie van Economische Zaken en Financiën. ${ }^{19} \mathrm{Wel}$ moet de CMA verantwoording afleggen aan het ministerie voor het gebruik van middelen. Sterker nog, de CMA is tot doel gesteld haar operationele kosten in tienvoud terug te verdienen in opbrengst voor consumenten. ${ }^{20}$ Voor de verwezenlijking van dit doel, samen met een verslag over de bredere maatschappelijke impact van haar werk, heeft de CMA een uitgebreide rapportageverplichting. Daarnaast heeft de regering bij het creëren van de CMA een strategisch stuurdocument opgesteld, dat - hoewel niet bindend - wel in overweging is genomen bij het opstellen van de CMA's strategische doelstellingen en haar prioriteringsbeleid. ${ }^{21}$

De strategische doelstellingen van de CMA zijn vijfledig: het nastreven van effectieve handhaving, het vergroten van mededinging op de markt, het herbezinnen op consumentenbescherming, het nastreven van professionaliteit in de organisatie en het bevorderen van een

16. Dat dit een belangrijke waarborg voor bedrijven biedt, blijkt uit het klassieke arrest ETB de Vos, waarin bepaald werd dat de afdeling die de boete oplegde geen feitelijke vragen meer mocht stellen aan de afdeling die het onderzoek deed. Zie CBb 30 augustus 2011, ECLI:NL:CBB: 2011:BR6737 (ETB de Vos).

17. Hoofdstuk 6 Algemene wet bestuursrecht, hoewel de mogelijkheid bestaat dit over te slaan. Zie Wet Rechtstreeks Beroep 2004.

18. Art. 25 lid 3 Enterprise and Regulatory Reform Act 2013.

19. Dat is, in het geval van de CMA, HM Treasury. Zie hierover uitgebreider CMA Annual Plan 2015/2016, Annex I, par. A.1

20. CMA Annual Plan 2015/2016, Annex I, par. A.2.

21. Competition Regime, Government's Strategic Steer to the Competition and Markets Authority, versie consultatie juli 2015 
geïntegreerde aanpak van problemen. ${ }^{22}$ Deze doelstellingen reflecteren de duale missie van de CMA (concurrentiebevordering én consumentenbescherming), maar laten ook zien dat de CMA veel nadruk legt op effectiviteit van de eigen organisatie. De hiervoor genoemde opbrengstverplichting voor consumenten indachtig, streeft de CMA naar eigen zeggen 'robuuste handhaving' na - hetgeen lijkt te wijzen op een nadrukkelijkere inzet van zwaardere, meer afschrikwekkende handhavingsinstrumenten. ${ }^{23}$

Met betrekking tot die handhavingsinstrumenten heeft de CMA - net als de Nederlandse en de Franse mededingingsautoriteit - de beschikking over verschillende, administratiefrechtelijke procedures, zoals het opleggen van een bestuurlijke boete of het nemen van een toezeggingsbesluit. ${ }^{24}$ Los van de bestuursrechtelijke mogelijkheden kan de CMA ook overgaan tot een strafrechtelijk onderzoek naar kartelovertredingen (cartel offence), of besluiten bestuurders van ondernemingen uit hun taak te ontheffen door middel van een director disqualification order. ${ }^{25}$ Dit zijn zware maatregelen, die het beeld van de CMA als 'sterke arm van de Mededingingswet' alleen maar onderstrepen. Aan de andere kant van het handhavingsspectrum heeft de CMA eveneens de mogelijkheid om zaken in een vroeg stadium informeel af te handelen. De CMA beschikt daarmee over een zeer volledig scala aan handhavingsinstrumenten.

Uit de beschrijving van het instrumentarium blijkt dat ook de CMA bevoegd is om zelfstandig onderzoek te doen en dienaangaande sancties op te leggen. Om onpartijdige besluitvorming te bevorderen maakt de CMA daarom gebruik van een Case Decision Group; een ad-hocteam dat verantwoordelijk is voor de eindbeslissing in een specifieke zaak. Er is geen institutionele functiescheiding zoals dat bij ACM (en ook bij de Autorité de la Concurrence, zie hierna) het geval is. Daarentegen wordt er in het Verenigd Koninkrijk meer nadruk gelegd op de rol van de rechter. Dit is overeenkomstig de common lam-traditie, waarbinnen een bestuursrechtelijk sanctiestelsel een vreemde eend in de bijt is. ${ }^{26}$ Binnen het Britse mededingingstoezicht vertaalt dit zich in het bestaan van een specialistische rechtbank (de Competition Appeals Tribunal) en een zware transparantie- en motiveringsplicht bij bestuursrechtelijke besluiten.

Autorité de la Concurrence (Frankrijk)

De Autorité de la Concurrence is de Franse mededingingsautoriteit en is - in tegenstelling tot de Nederland-

22. Competition and Markets Authority, CMA 13, Vision, Values and Strategy for the CMA, januari 2014.

23. Dit is vanuit de ontstaanshistorie van de CMA goed te begrijpen. De voormalige Office of Fair Trading legde tijdens haar bestaan nauwelijks boetes op, maar had een meer brede aanpak van markten. Zie Lachnit 2016, hfdst. 2.

24. Art. 31A en 36 Competition Act 1998.

25. Voor de strafrechtelijke sancties zie art. 188 Enterprise Act 2002 jo. 47a Enterprise and Regulatory Reform Act 2013. Voor een diskwalificatie, zie art. 9a tot 9e Company Directors Disqualifications Act 1986.

26. Zie voor de ontwikkeling van de mededingingsrechtelijke handhavingstraditie in een common law rechtssysteem: A. Scot, 'The Evolution of Competition Law and Policy in the United Kingdom', LSE Law, Society and Economy Working Papers 2009, nr. 9. se en Britse toezichthouder - een single function autoriteit, hetgeen inhoudt dat de Autorité zich alleen bezighoudt met mededingingstoezicht. In haar huidige vorm bestaat de Autorité sinds 2009. Daarvoor was zij als Conseil de la Concurrence onderdeel van het ministerie van Economische Zaken. De missie van de Autorité is 'het bewaken van de vrije mededinging en het ondersteunen van concurrentie op de nationale en Europese markt ten behoeve van het bewaken van de publieke economische orde en de welvaart van de consument'. ${ }^{27}$

De interne organisatie van de Autorité kent een sterke scheiding tussen de onderzoeksafdeling enerzijds en het college van bestuur anderzijds. De onderzoeksafdeling is verantwoordelijk voor het uitvoeren van onderzoeken naar overtredingen van de mededingingsregels, het college van bestuur is verantwoordelijk voor het kiezen en opleggen van de uiteindelijke sanctie. Deze strikte functiescheiding vormt derhalve (net als de Nederlandse Chinese Walls en de Britse Case Decision Group) een waarborg voor onpartijdige besluitvorming. Daarnaast heeft de Autorité een Hearing Officer, die fungeert als ombudsman voor bedrijven die zich onbehoorlijk bejegend voelen tijdens een onderzoek of procedure. ${ }^{28}$

Historisch gezien heeft de politiek in Frankrijk een sterke invloed op het functioneren van de economie, en dus ook op het functioneren van de mededingingsautoriteit. ${ }^{29}$ Hoewel de Autorité formeel een onafhankelijke autoriteit is en op operationeel niveau zelfstandig kan opereren, is deze invloed op beleidsniveau vaak nog voelbaar. Veranderingen in de taakstelling van de Autorité lopen vaak parallel aan veranderingen in de politiek en de dan heersende visie op de planning van de economie. Zo heeft de Autorité tijdens de laatste regeringsperiode een fikse uitbreiding van haar handhavingsinstrumentarium gekregen, omdat dit nodig werd geacht om de Franse economie - na de economische crisis - competitiever te maken. ${ }^{30}$

Ook in de taakstelling van de Autorité is de invloed van de minister van Economische Zaken duidelijker dan in de andere twee landen. De Autorité heeft, naast een handhavingsfunctie, namelijk ook een expliciete adviesfunctie. ${ }^{31}$ Dit houdt in dat ministeries verplicht zijn om de Autorité om advies te vragen wanneer zij regelgeving maken die invloed kan hebben op de marktwerking. De Autorité is vervolgens verplicht om dienaangaande een

27. Zeer vrij vertaald uit de Code de Commerce, art. L.461-1, par. I: 'Au service du consommateur, elle a pour objectif de veiller au libre jeu de la concurrence et d'apporter son concours au fonctionnement concurrentiel des marchés aux échelons européen et international' en 'L'Autorité de la concurrence est une autorité administrative indépendante, spécialisée dans l'analyse et la régulation du fonctionnement de la concurrence sur les marchés, pour la sauvegarde de l'ordre public économique'.

28. Zie Autorité de la Concurrence, Organisation de l'Autorité de la Concurrence (version 2015).

29. Zie uitgebreider A. Künzler en L.Warlouzet, 'National Traditions of Competition Law: A Belated Europeanization through Convergence?', in: K.K. Patel en H.H. Schweiter (red.), The Historical Foundations of EU Competition Law, Oxford: Oxford University Press 2013, p. 89-124.

30. Loi n $2015-990$ du 6 août 2015 pour la croissance, l'activité et l'égalité des chances économiques.

31. De bevoegdheid daartoe komt uit art. L. 410-2 en L. 462-2 Code de Commerce. 
impact assessment uit te voeren. De adviestaak van de Autorité vormt een groot deel van haar werkzaamheden. Jaarlijks publiceert zij gemiddeld zo'n 23 adviezen, tegenover gemiddeld 20 handhavingsbesluiten. Met betrekking tot de handhaving heeft de Autorité de beschikking over verschillende formele instrumenten, zoals een bestuurlijke boete, een toezeggingsbesluit of een bindende aanwijzing. ${ }^{32} \mathrm{Bij}$ het toepassen van deze instrumenten streeft de Autorité twee belangrijke strategische doelen na: het vergroten van haar eigen efficiëntie, maar ook het vergroten van de procedurele rechtvaardigheid. ${ }^{33} \mathrm{Om}$ dit laatste doel te bereiken maakt de Autorité voor al haar handhavingsinstrumenten gebruik van gedetailleerde beleidsregels. ${ }^{34}$

De Autorité maakt minder gebruik van instrumenten aan de informele kant van het spectrum. Dit valt, juridisch-historisch gezien, te verklaren door het Franse legaliteitsbeginsel dat stamt uit een oude, bestuursrechtelijke traditie. ${ }^{35}$ De interpretatie van het legaliteitsbeginsel in Frankrijk is formalistisch; het dient ervoor te zorgen dat het bestuur zich bij de uitvoering van zijn taken aan de relevante wetten en statuten houdt. ${ }^{36}$ Wanneer dit niet gebeurt, kan het bestuursorgaan aansprakelijk worden gesteld voor eventuele schade. ${ }^{37}$ Een concrete uiting van de toepassing van het legaliteitsbeginsel in de context van het mededingingstoezicht is bijvoorbeeld dat de Autorité - anders dan de Nederlandse en Britse autoriteit - zaken niet kan 'wegprioriteren' of kan sluiten om administratieve redenen. Iedere afwijzing van een klacht of sluiting van een onderzoek dient uitgebreid te worden gemotiveerd met verwijzing naar de wettelijke gronden waarop dit gebeurt. Hierdoor is er minder ruimte voor informele afhandeling van zaken. ${ }^{38}$

Korte vergelijking op kernpunten

Met betrekking tot vormgeving van de toezichthouder als agency kan worden gesteld dat het mededingingstoezicht in deze drie landen wordt uitgevoerd door onafhankelijke toezichthouders, die in mindere (Verenigd Koninkrijk) of meerdere mate (Frankrijk) in hun dagelijkse bezigheden kunnen worden gestuurd door de

32. Zie art. L.464-2 par. I, II en III Code de Commerce.

33. Deze doelen komen het duidelijkst naar voren in B. Lasserre, 'The new French competition law enforcement regime', Competition Law International 2009.

34. Zie voor de relevante beleidsregels de analyse van de handhavingsinstrumenten hierna, in 'Alternatieve handhavingsinstrumenten'.

35. Het Franse bestuursrechtelijke systeem stamt uit 1789. Het is uiteraard aan verandering onderhevig geweest, maar is een van de oudste bestuursrechtelijke systemen van Europa. Zie J.B. Auby, 'Administrative law in France', in: R. Seerden en F. Stroink, Administrative Law of the European Union, its Member States and the United States, Antwerpen/ Groningen: Intersentia 2002, p. 59-89.

36. In tegenstelling tot, bijvoorbeeld, de interpretatie waarbij het legaliteitsbeginsel de burger dient te beschermen tegen ongerechtvaardigd ingrijpen van het bestuur. Zie voor een praktische discussie van de betekenissen van het legaliteitsbeginsel in verschillende contexten C.J.H. Jansen en J.J.J. Sillen (red.), In extenso: Het legaliteitsbeginsel vanuit zeven invalshoeken belicht, Nijmegen: Ars Aequi Libri 2012.

37. Zie voor een uitgebreidere verhandeling over de rol van het legaliteitsbeginsel in het Franse bestuursrecht Auby 2002.

38. Deze veronderstelling wordt onderschreven in Lachnit 2016, waarbij er in interviews met medewerkers van de Autorité aandacht is besteed aan dit punt. betrokken minister, maar alle ten minste budgettaire verantwoording schuldig zijn aan het verantwoordelijke ministerie of aan het parlement. In de interne organisatie hebben alle drie de toezichthouders structuren om onpartijdige besluitvorming te waarborgen, zij het op institutionele basis (Nederland, Frankrijk) of op ad-hocbasis (Verenigd Koninkrijk).

In taakstelling verschillen de drie toezichthouders enorm. De Nederlandse ACM is een multitoezichthouder, de Britse CMA heeft een duale functie en de Franse Autorité is een single function autoriteit. Bij het uitvoeren van deze functies ligt de focus van de autoriteiten respectievelijk (en enigszins gechargeerd) bij het probleemoplossend vermogen, het nastreven van robuuste handhaving en het vergroten van procedurele rechtvaardigheid. Dit verschil in focus is belangrijk en wordt, zoals hierna blijkt, gereflecteerd in de manier waarop er met de alternatieve handhavingsinstrumenten wordt omgegaan.

Tot slot is het juridisch en procedureel nog van belang dat er in Nederland gebruik wordt gemaakt van bestuurlijke heroverweging (de bezwaarprocedure), dat er in het Verenigd Koninkrijk veel belang wordt gehecht aan beroep bij een rechter, waardoor er een zware transparantieverplichting op de CMA drukt, en dat een strikte interpretatie van het legaliteitsbeginsel in Frankrijk zijn sporen nalaat in de discretionaire bevoegdheid die de Autorité heeft bij haar besluitvorming.

Deze kernpunten, die hier zeer verkort zijn weergeven, zijn van belang bij het waarderen van de alternatieve handhavingsinstrumenten hierna en zorgen ervoor dat de bredere conclusies die daarop volgen in de juiste context kunnen worden geplaatst.

\section{Alternatieve handhavingsinstrumenten}

Zoals hiervoor gedefinieerd is 'alternatieve handhaving' geen gesloten categorie van instrumenten. Elk handhavingsinstrument dat naar zijn aard een afwijking inhoudt van de meer klassieke of reguliere instrumenten behoort in principe onder deze noemer. In deze bijdrage wordt er aandacht besteed aan vier typen alternatieve handhavingsinstrumenten: de schikking in brede zin, de marktstudie in brede zin, de individuele zienswijze en het compliance-programma. Deze instrumenten vormen een goede illustratie van alternatieve handhaving in het mededingingstoezicht, maar hebben bovendien verschillende kenmerken die ze alternatief maken in de zin van de eerdergenoemde definitie. Zo is een schikking (ten opzichte van een reguliere procedure) meer horizontaal van aard vanwege het element van overleg, is een marktstudie meer breed toepasbaar en informatief, is een individuele zienswijze doorgaans informeel van aard en dienen compliance-programma's ter preventie van overtredingen, in plaats van een reactie achteraf. Deze vier handhavingsinstrumenten worden kort besproken, waar- 
bij er met name aandacht is voor de onderlinge verschillen tussen de mededingingsautoriteiten en de doelen die zij met de toepassing van deze instrumenten nastreven.

\section{Schikking in brede zin}

Schikkingsprocedures in brede zin lijken erg op reguliere boeteprocedures, ${ }^{39}$ met dien verstande dat er een moment is ingebouwd waarop autoriteit en ondernemingen overleggen over de te nemen procedurele stappen. Meestal draait het dan om het niet-betwisten van de feiten en de juridische analyse (door de ondernemingen) in ruil voor een boetekorting (gegeven door de autoriteit). Het niet-betwisten van de feiten en juridische analyse houdt in dat de onderneming zich neerlegt bij de bezwaren die de mededingingsautoriteit op basis van een formeel onderzoek kenbaar makkt. Hierdoor geven de ondernemingen een deel van hun recht om gehoord te worden op, waarna er direct over kan worden gegaan tot het opleggen van de boete.

In Frankrijk heet een schikking een transactie (transaction), waartoe de Autorité reeds in 2001 de bevoegdheid kreeg. Deze bevoegdheid is neergelegd in een formele wet en is - in overeenstemming met het hiervoor beschreven legaliteitsbeginsel - verder uitgewerkt in een richtsnoer. ${ }^{40}$ De Autorité past de transactie strikt volgens deze richtsnoeren toe, en doet dat regelmatig: zo'n een op de vijf boetes is het resultaat van een transactieprocedure. Het bijzondere aan de Franse transactie is dat bedrijven - in ruil voor additionele boetekorting vaak bindende toezeggingen doen om de mededinging op de markt structureel te verbeteren. Tegenover de langere schikkingstraditie van Frankrijk staat de praktijk van 'vereenvoudigde afdoening' van ACM. Deze bevindt zich nog in een opstartfase en is nog niet uitgekristalliseerd in beleidsregels of richtsnoeren. ACM kan overgaan tot vereenvoudigde afdoening op basis van de bestaande Boeterichtsnoeren, die enige ruimte laten voor het waarderen (in boetekorting) van verregaande procedurele medewerking van bedrijven. ${ }^{41}$ In Nederland is de vereenvoudigde afdoening vooralsnog slechts in enkele zaken toegepast. ${ }^{42}$ Ergens tussen deze twee uitersten bevindt zich de aanpak van de Britse CMA, die zonder expliciete juridische basis ontwikkeld is in de praktijk, maar recentelijk wel is geformaliseerd in procedurele richtsnoeren. Zowel in Nederland als in Frankrijk blijft de functionele scheiding tussen onderzoek en boeteoplegging van kracht bij een schikking in brede zin, omdat het een formele boeteprocedure betreft. In het Verenigd Koninkrijk is dit echter niet zo; de Case Decision Group wordt hier omwille van efficiëntie juist achterwege gelaten. De CMA noemt dit instrument een

39. Er wordt gesproken over schikkingsprocedures in brede zin, omdat de Britse variant een 'schikking' heet. Om verwarring te voorkomen wordt er gesproken over schikkingen in enge zin (de Britse variant) en schikkingen in brede zin (het overkoepelende begrip).

40. Op basis van art. L.464-2, par. III van de Code de Commerce, verder uitgewerkt in Autorité de la Concurrence, 'Communiqué de procédure du 10 février 2012 relatif à la non-contestation des griefs'.

41. Zie Beleidsregels voor Boete en Clementie, Stcrt. 2013, 11214, randnr. 19.

42. Zie bijvoorbeeld ACM, zaak 14.0705.27 (Azijn). schikking in enge zin (settlement), en past dit sinds 2008 in toenemende mate toe in haar handhavingspraktijk. ${ }^{43}$ Dit is in overeenstemming met de strategische doelen van de CMA, die zien op snelle en meer robuuste handhaving. ${ }^{44}$

Het doel van een schikking in brede zin is om een boeteprocedure te versnellen, zowel in het belang van de mededingingsautoriteit als van de betrokken bedrijven. Schikkingen in brede zin worden daarom vaak toegepast uit efficiëntieoverwegingen. Hoewel het lastig is om de tijdsduur van individuele zaken met elkaar te vergelijken, wordt geschat dat een schikking in brede zin een procedure met enkele maanden tot een jaar kan inkorten. ${ }^{45}$ Echter, de verplichtingen die rusten op bedrijven bij een schikking in brede zin staan op gespannen voet met hun procedurele rechten. Bedrijven geven namelijk een deel van hun verdedigingsrechten op, terwijl het definitieve besluit nog niet genomen is. ${ }^{46}$ Wanneer er een schikking wordt toegepast, moet er derhalve een goede afweging worden gemaakt tussen de efficiëntiebelangen enerzijds en de rechten van bedrijven anderzijds. Deze balans zal van zaak tot zaak bepaald moeten worden. Ook dienen mededingingsautoriteiten (en toezichthouders in het algemeen) zich bewust te zijn van het feit dat een overlegmoment met partijen extra risico tot regulatory capture met zich meebrengt, die wellicht minder snel aan het licht komt omdat er geen bezwaar- en beroepsfase zal zijn. Een goed afgebakende procedure (inclusief waarborgen om capture te voorkomen) kan dit risico minimaliseren. ${ }^{47}$

\section{Marktonderzoek in brede zin}

Marktonderzoek in brede zin kan gedefinieerd worden als een studie naar het functioneren van een bepaalde markt, naar aanleiding waarvan er een rapport met bevindingen wordt gepubliceerd. ${ }^{48}$ Een marktonderzoek kan als verkenning van nieuwe of complexe markten worden toegepast, maar ook als het vermoeden bestaat dat bepaalde markten niet goed werken. Op basis van een marktonderzoek kan een mededingingsautoriteit vervolgstappen nemen, zoals het doen van aanbevelin-

43. In totaal heeft de CMA veertien maal een schikking getroffen sinds 2008, waarvan zes in de laatste drie jaren.

44. Zie de beschrijving van de strategie van de CMA in 'Typering nationale autoriteiten' hiervoor.

45. Op basis van vergelijking tijdsduur boetebesluiten en transacties in Frankrijk tussen 2004 en 2012. Zie Lachnit 2016, hfdst. 4

46. Op basis van jurisprudentie van het Hof van Justitie en het Europees Hof voor de Rechten van de Mens lijkt dit onder specifieke voorwaarden geen doorkruising op te leveren van het recht op een eerlijk proces. De toetsing door de rechter is hierin een cruciale voorwaarde. Zie EHRM, application no. 43509/08 (Menarini Diagnostics v. Italy) en in EU-rechtelijke context HvJ EU 8 december 2011, zaak C-389/10 P (KME) en zaak C-386/10 P (Chalkor).

47. Deze aanbeveling vindt niet alleen plaats op basis van de bevindingen die in dit stuk over het voetlicht worden gebracht, maar heeft een basis in het proefschrift van de auteur, zie Lachnit 2016.

48. $\mathrm{Er}$ is - afgaande op de terminologie die de mededingingsautoriteiten zelf gebruiken - onduidelijkheid over de naam van dit instrument. Het regime van de CMA bestaat uit marktstudies en marktonderzoeken, ACM maakt afwisselend gebruik van marktscans, marktonderzoeken of marktstudies en de Autorité spreekt van zelfverwijzingen. Overkoepelend is derhalve de term 'marktonderzoek in brede zin' gebruikt. 
gen of het overgaan op een formeel onderzoek naar een overtreding. De uitkomsten van marktonderzoeken in brede zin zijn - een Britse uitzondering daargelaten geen formeel besluit, en derhalve niet bindend.

Binnen deze categorie van handhavingsinstrumenten verschillen de drie nationale praktijken aanzienlijk. Het meest opvallend is het geformaliseerde en uitgekristalliseerde markets mork regime van de CMA; een unieke procedure bestaande uit twee fasen. De eerste fase (de marktstudie) heeft een verkennend karakter en is vooral bedoeld om de markt en marktproblemen in kaart te brengen. De tweede fase (het marktonderzoek) is veel formeler en is omkleed met procedurele waarborgen, zoals een strikte transparantieverplichting en een zware motiveringsplicht. ${ }^{49}$ De reden hiervoor is dat de CMA op basis van een marktonderzoek bindende aanwijzingen kan geven tot het verbeteren van de markt op individueel ondernemingsniveau. Zo kan de CMA bijvoorbeeld een price cap opleggen, of vaststellen dat bepaalde bedrijfsonderdelen dienen te worden afgestoten. ${ }^{50}$ Deze verregaande maatregelen zijn in Frankrijk of Nederland niet mogelijk. De Autorité heeft namelijk een vrij beperkte bevoegdheid om marktonderzoek te doen, en deed dit aanvankelijk enkel op aanvraag van andere overheidsinstanties in het kader van de adviesprocedure. ${ }^{51}$ Hoewel de Autorité nu wel de bevoegdheid heeft om uit eigen beweging onderzoek te doen, doet zij dat relatief weinig. ${ }^{52}$ In de toepassing van dit instrument is derhalve de invloed van de politiek goed te herkennen. ACM heeft iets meer flexibiliteit dan de Autorité op dit gebied, en doet marktonderzoek met een variabel niveau van intensiteit en formaliteit. ${ }^{53} \mathrm{Wel}$ is er sinds de totstandkoming van ACM een wettelijke bevoegdheid tot het doen van marktonderzoek en het vergaren van informatie hiervoor, hetgeen overeenkomt met de strategische wens van ACM om in het kader van probleemoplossend toezicht het gehele instrumentarium breed in te kunnen zetten. ${ }^{54}$ Zowel ACM als de Autorité kan naar aanleiding van een marktonderzoek enkel aanbevelingen aan de markt doen (of, in een later stadium, overgaan tot het openen van een formeel onderzoek naar een inbreuk).

De doelstellingen van marktonderzoek in brede zin verschillen per lidstaat: het bewerkstelligen van compliance door voorlichting, het verzamelen van kennis over de markt of het genereren van publiciteit. In ieder geval is

49. De transparantieverplichtingen zien onder andere op het formeel kenbaar maken van enkele landmark moments in de procedure en het ter consultatie aanbieden van de eerste versie van het onderzoek. Marktonderzoeken van de CMA zijn erg gedetailleerd, en omvatten vaak meer dan duizend pagina's. Zie verwijzing naar richtsnoeren hieronder.

50. Zie Competition Commission, Guidelines for market investigations: Their role, procedures, assessment and remedies, CC3 (revised), april 2013.

51. Art. L. 410-2 en L. 462-2 Code de Commerce.

52. Art. L.462-4 Code de Commerce.

53. Sommige onderzoeken zijn heel uitgebreid en worden deels uitgevoerd door externe onderzoeksbureaus, andere zijn juist erg beknopt en geven informatie over de markt weer op hoofdpunten (meestal 'scans' genaamd)

54. Zie art. 1B (par. 3-6), 6B, 7 en 12M Stroomlijningswet 2014, zie verder ACM, Strategie Autoriteit Consument en Markt, 20 september 2013. marktonderzoek gericht op een brede aanpak van de markt, idealiter ex ante. Marktonderzoek in brede zin kan echter ook een negatief effect hebben op de handhaving- en geloofwaardigheid van mededingingsautoriteiten. Dergelijk onderzoek kan - zeker in combinatie met andere handhavingsactiviteiten - de indruk wekken dat de autoriteit zich te veel focust op één markt (over-involvement), het kan ervoor zorgen dat bedrijven zich anders gaan gedragen en overcompenseren uit vrees voor handhavingsactie (over-commitment) en het kan tot gevolg hebben dat autoriteiten marktonderzoek toepassen in markten waarin de mededinging dusdanig verstoord is dat die zich beter zouden lenen voor een formeel onderzoek naar een inbreuk (under-enforcement). Deze risico's zouden kunnen worden geminimaliseerd door strikte criteria te formuleren voor de toepassing van marktonderzoek. Gezien de doelstellingen van het instrument kan worden gesteld dat marktonderzoek het best kan worden toegepast in complexe markten of markten in ontwikkeling, of in aanwezigheid van bredere marktproblematiek. ${ }^{55}$ Het is daarom niet verwonderlijk dat veel marktonderzoeken worden toepast in (delen van) de zorgmarkt, in de financiële sector of in digitale markten. ${ }^{56}$ Wanneer er sprake is van marktverstoringen door het gedrag van enkele spelers, of als het gaat om een (type) markt waar de mededingingsautoriteit goed bekend mee is, is een marktonderzoek om eerdergenoemde redenen minder opportuun.

\section{Individuele zienswijzen}

Waar een marktonderzoek in brede zin aanbevelingen over het voetlicht brengt voor de gehele markt, doet een individuele zienswijze dit op bedrijfs- of afspraakniveau. Dit instrument is erop gericht om (groepen van) ondernemingen van advies te voorzien over hun voorgenomen acties en mogelijke strijd met mededingingsrecht. Een dergelijk advies wordt gevraagd op initiatief van de bedrijven en kan door een mededingingsautoriteit worden gegeven indien het een nieuwe en onbeantwoorde rechtsvraag betreft. ${ }^{57}$ De zienswijze van de mededingingsautoriteit wordt $e x$ ante afgegeven en is informeel van aard. De beantwoording van de rechtsvraag is dus niet juridisch bindend en ook niet appellabel.

55. Deze typering vindt niet alleen plaats op basis van de bevindingen die in dit stuk over het voetlicht worden gebracht, maar heeft een basis in het proefschrift van de auteur, zie Lachnit 2016.

56. In Nederland is er bijvoorbeeld recentelijk onderzoek gedaan naar de farmaciemarkt (ACM, Farmacie onder de loep - Kansen voor toetreding generieke geneesmiddelen en keuzes voor patiënten, februari 2015), en de zakelijke SMS-markt (ACM, Marktscan Zakelijke SMS-markt, no. ACM/DTVP/2014/202774_OV).

57. Over het algemeen geven mededingingsautoriteiten een individuele zienswijze af indien: (1) het een nieuwe, onbeantwoorde rechtsvraag betreft, (2) er sprake is van een groot maatschappelijk of economisch belang bij beantwoording ervan, (3) de voorgenomen overeenkomst of gedraging nog niet is geïmplementeerd, maar (4) ook niet hypothetisch is. De mededingingsautoriteiten doen doorgaans niet zelf onderzoek naar de afspraak, de benodigde informatie dient door partijen zelf aangeleverd te worden. Zie Competition and Markets Authority, Guidance on the CMA's approach to short-form opinions, CMA27, april 2014, Autorité de la Concurrence, 11-A-17 (Déchets de I'Eau), par. 22, 26 en 28 en Vuistregels Informele Zienswijzen, Stcrt. 2010, 266724 
De Autorité geeft dergelijke zienswijzen in het kader van haar eerder genoemde adviestaak. De procedure voor het geven van advies heeft een hybride karakter en vertoont eveneens trekken van advocacy en marktonderzoek. Niet iedere onderneming kan om een individuele zienswijze vragen. Alleen bepaalde aangewezen brancheorganisaties, consumentenorganisaties of overheidsorganen hebben dit recht. ${ }^{58}$ Mede hierom geeft de Autorité weinig zienswijzen in individuele zaken af. De CMA geeft individuele zienswijzen door middel van een short-form opinion. Hoewel dit instrument voor de totstandkoming van de CMA niet vaak werd gebruikt, ${ }^{59}$ is er toch besloten om die mogelijkheid voor bedrijven open te houden. Noch de Autorité noch de CMA doet in een individuele zienswijze concrete uitspraken over de juridische houdbaarheid van de voorgelegde afspraak. In plaats daarvan bieden zij een denkkader voor self assessment dat toegepast kan worden op de afspraak. Dit is anders in Nederland, waar ACM zich doorgaans wel duidelijk uitspreekt over de compatibiliteit van een voorgenomen afspraak binnen het mededingingsrecht. ${ }^{60}$ De procedures en voorwaarden voor het afgeven van een individuele zienswijze waren in een zogenoemde Vuistregel opgenomen, ${ }^{61}$ maar ACM heeft in de loop der jaren ook zienswijzen afgegeven buiten voorwaarden uit de Vuistregel om. ${ }^{62}$ Hoewel de Vuistregel inmiddels is ingetrokken, is ACM nog steeds een van de actiefste mededingingsautoriteiten op dit gebied. ${ }^{63}$

Het doel van een individuele zienswijze is dus om vooraf duidelijkheid te geven over complexe juridische vragen. Hoewel individuele zienswijzen in alle drie de lidstaten gebruikt worden, lijkt het alsof het instrument in zijn huidige vorm niet goed werkt. Sommige mededingingsautoriteiten zijn erg terughoudend met het gebruik ervan (CMA, Autorité), terwijl andere juist buiten de bestaande kaders een nieuw instrument hebben ontworpen (ACM, door het geven van zienswijzen buiten de Vuistregel om). Beide houdingen kunnen deels worden verklaard door het effect dat een zienswijze kan hebben

58. Zie art. L. 410-2 en L. 462-2 Code de Commerce.

59. Slechts driemaal: Newspaper and magazine distribution, Opinion of the Office of Fair Trading (...) OFT 1025, oktober 2008, P\&H/Makro Joint Purchasing Agreement, Short-form Opinion of the Office of Fair Trading (...) 27 april 2010 en Rural Broadband Wayleave Rates, Shortform Opinion of the Office of Fair Trading (...), 23 augustus 2012.

60. Denk aan veelbesproken voorbeelden als het Energieakkoord (ACM, Analyse van de Autoriteit Consument en Markt met betrekking tot de voorgenomen afspraak tot sluiting van 80er jaren kolencentrales in het kader van het SER Energieakkoord, 2013) en de Kip van Morgen (ACM, Analyse ACM van duurzaamheidsafspraken 'De Kip van Morgen', ACM/DM/2014/206028, 2015)

61. Vuistregels Informele Zienswijzen, Stcrt. 2010, 266724.

62. Dit worden onregelmatige zienswijzen genoemd, en ze voldoen bijvoorbeeld niet aan de voorwaarde dat het moet gaan om een nieuwe rechtsvraag, of aan het vereiste dat bedrijven zelf de onderliggende informatie moeten aanleveren (ACM deed in deze zienswijzen ook zelfstandig onderzoek naar de effecten van de afspraak). Zie uitgebreider Lachnit 2016, hfdst. 6

63. De laatste versie hiervan waren de hiervoor genoemde Vuistregels, die bij de totstandkoming van ACM zijn ingetrokken. ACM heeft in totaal 89 zienswijzen gegeven (waarvan 22 over mogelijk mededingingsbeperkende afspraken), waarvan een toegenomen aantal in de laatste jaren. op de partijen die het aanvragen. Hoewel een zienswijze niet bindend is, kunnen bedrijven het toch als zodanig ervaren. Hierdoor kan de situatie ontstaan dat bedrijven de zienswijze ervaren als een geruststelling, dan wel een verbod, zonder dat er de mogelijkheid is voor een rechter om zich te buigen over de analyse die de mededingingsautoriteit uitvoerde. ${ }^{64}$ Mede om deze reden is er veel discussie over de wenselijkheid van dit handhavingsinstrument en wordt betoogd dat autoriteiten hier terughoudend in moeten zijn. ${ }^{65}$ Aan de andere kant zijn mededingingsautoriteiten juist zeer goed in staat om toelichting te geven over de toepassing van mededingingsrecht. Een compromis tussen beide posities kan worden gevonden door een strikte capaciteitslimiet aan te houden en individuele zienswijzen alleen in te zetten voor bredere nieuwe en onopgeloste vragen. Daarnaast zou er - zeker indien er duidelijke uitspraken worden gedaan over de houdbaarheid van de voorgelegde afspraak - gebruik kunnen worden gemaakt van een consultatie om te waarborgen dat de analyse in de zienswijze overeenkomt met wat stakeholders en het publiek van de autoriteit verwachten. Indien dit niet het geval is, kan dit een teken zijn om niet tot het geven van een zienswijze over te gaan.

\section{Compliance-programma's}

Compliance-programma's zijn plannen van aanpak, opgesteld door bedrijven, om ervoor te zorgen dat diverse wetten zo goed mogelijk worden nageleefd. Het stimuleren van compliance-programma's is niet expliciet een wettelijke taak voor mededingingsautoriteiten, maar wordt wel vaak gezien als aanvullende taak in het kader van hun bredere handhavingsstrategieën. ${ }^{66}$ Complianceprogramma's kunnen heel beknopt zijn (een nalevingshandvest), maar ook heel uitgebreid (regelmatige trainingen, een gespecialiseerde afdeling, een compliance officer). Mededingingsautoriteiten kunnen het opstellen van dergelijke programma's stimuleren, hier voorlichting over geven en zelfs de belofte om een complianceprogramma te introduceren bindend laten verklaren in het kader van een toezeggingsbesluit of een schikking in brede zin.

De CMA, de Autorité en ACM zijn elk op hun eigen manier actief op dit gebied. De Autorité hanteert een geformaliseerde aanpak voor het stimuleren van compliance-programma's en heeft, net als voor haar andere instrumenten, uitgebreide richtsnoeren opgesteld waar-

64. Dit is enigszins gechargeerd. Enkele mogelijkheden zijn er wel, zowel in administratief recht (het uitlokken van een formeel onderzoek, of een ultra vires-procedure) of in civiel recht (het verzoeken om een verklaring voor recht dat de gemaakte analyse onjuist is). Zie hierover E.S. Lachnit, 'Mededingingsautoriteiten als Koorddansers: spanningen rond individuele zienswijzen, SEW 2016-12, p. 521-532.

65. Zie hierover een kritische beschouwing van A. Gerbrandy, 'Informele oordelen, de koning van Frankrijk, Khaleesi en Frank Underwood', M\&M 2015/2, p. 89-90.

66. Zie over het stimuleren van compliance als missie van mededingingsautoriteiten uitgebreider E.S. Lachnit, 'Compliance Programmes in Competition Law - Improving the Approach of Competition Authorities', Utrecht Law Review 2014, vol. 10, nr. 5. 
aan een goed compliance-programma dient te voldoen. ${ }^{67}$ De Autorité verklaart de intentie tot het opstellen ervan vaak verbindend in het kader van een transactie, en verbindt daar een additionele boetekorting aan. ${ }^{68}$ De CMA is eveneens erg actief in het stimuleren van compliance en heeft zich - vooral voor de institutionele veranderingen in 2014 - erg gefocust op het publiceren van toegankelijke materialen die het belang van naleving benadrukken. ${ }^{69}$ Daarnaast is de CMA de enige mededingingsautoriteit die een boetekorting geeft in een reguliere procedure voor het bestaan van een compliance-programma. ${ }^{70}$ Met betrekking tot stimulering van compliance-programma's in het bijzonder is de aanpak van ACM nog het voorzichtigst, in de zin dat er geen duidelijke richtsnoeren zijn waaraan een programma dient te voldoen. ${ }^{71} \mathrm{Wel}$ maakt ACM veelvuldig gebruik van (sociale) media om haar werk, en daarmee ook het belang van regelnaleving, voor het voetlicht te brengen. ${ }^{72}$

Hoewel de primaire verantwoordelijkheid voor naleving bij bedrijven ligt, kan het stimuleren van complianceprogramma's een positieve stimulans tot regelnaleving bieden door de toepassing van de regels op bedrijfsniveau te verhelderen en zo commitment van bedrijven te vergroten. ${ }^{73}$ Echter, om bedrijven ertoe te zetten daadwerkelijk compliant te zijn, is het nodig een geloofwaardige en afschrikwekkende boetepraktijk achter de hand te hebben (stick-and-carrot-benadering). ${ }^{74} \mathrm{Het}$ is dan ook een van de meest betwiste punten van dit instrument of het enkele hebben van een compliance-programma voldoende is om in aanmerking te komen voor een boetekorting, ingeval er een inbreuk is vastgesteld. Blijkens de praktijk van de CMA zou dit mogelijk moeten zijn, mits mededingingsautoriteiten zich bewust zijn van het verschil tussen daadwerkelijk commitment en mindom

67. Autorité de la Concurrence, 'Document-cadre du 10 février 2012 sur les programmes de conformité aux règles de concurrence'.

68. Zie in Autorité de la Concurrence, 'Communiqué de procédure du 10 février 2012 relatif à la non-contestation des griefs'.

69. Enkele voorbeelden zijn: Office of Fair Trading, Quick Guide to Competition Law Compliance - Protecting businesses and consumers from anti-competitive behaviour, 2009. Office of Fair Trading, Four Step Compliance Process ('Wheel of Compliance'), 2011. Office of Fair Trading, OFT 1341, How your business can achieve compliance with competition law, juni 2011. Van latere datum is er ook: Competition and Markets Authority, Competition Law Risk - a short guide, The Institute of Risk Management, 2014

70. Zie Office of Fair Trading, OFT's guidance as to the appropriate amount of a penalty, OFT423, september 2012 - die is aangenomen door het bestuur van de CMA na de samenvoeging.

71. Overigens is er een discussie of dit überhaupt wel dient te bestaan. Moeten compliance-programma's eigenlijk niet altijd tailor made zijn? Zie bijvoorbeeld D.D. Sokol, 'Cartels, Corporate Compliance, and What Practitioners Really Think About Enforcement', University of Florida Scholarship Repository, Faculty Publications, 2012, maar ook een kritische noot van R. Elkerbout, 'Robuuste complianceprogramma's verdienen meer dan een lippendienst van de ACM', Tijdschrift Mededingingsrecht in de praktijk 2014, nr. 3, p. 26-31.

72. Zoals het publieksfilmpje waarin ACM suggereert (letterlijk) een fly on the wall te zijn bij kartelbesprekingen. Zie online: <https://vimeo.com/ 171773723>

73. Zie hierover bijvoorbeeld J.G. van Erp, 'Motieven voor naleving van regelgeving', in: T. Barkhuysen, W. den Ouden en J.E.M. Polak (red.), Recht realiseren. Bijdragen rond het thema adequate naleving van rechtsregels, Deventer: Kluwer 2005.

74. Van Erp 2005. dressing. Dit houdt in dat er alleen een boetekorting kan worden gegeven indien het compliance-programma aan enkele voorwaarden voldoet, en de onderneming de overtreding zelf heeft gerapporteerd. Zoals gesteld werd door de bestuursvoorzitter van ACM: 'Compliance is welbegrepen eigenbelang. ${ }^{75}$

\section{Typering praktijk nationale autoriteiten}

Met de schets van de drie mededingingsautoriteiten en de korte beschrijving van de verschillende alternatieve handhavingsinstrumenten in het achterhoofd is het mogelijk om de handhavingspraktijk van de nationale autoriteiten (en de plaats van alternatieve handhaving daarbinnen) te typeren. ${ }^{76}$ Hierbij draait het om de vraag hoe de invulling van de verschillende instrumenten zich verhoudt tot hoe de mededingingsautoriteit zich presenteert als toezichthouder. Daarbij is er ook aandacht voor de hiervoor besproken nationaalrechtelijke aspecten die wellicht invloed hebben op de manier waarop de mededingingsautoriteiten het toezicht inrichten.

\section{Alternatieve handhaving binnen Frans mededingingstoezicht}

Zoals blijkt uit de beschrijving hiervoor zijn de meeste alternatieve handhavingsinstrumenten die in het Franse mededingingstoezicht worden gebruikt formele (of geformaliseerde) procedures waarbij de Autorité weinig beoordelingsvrijheid geniet. Wanneer er wel sprake is van beoordelingsvrijheid is deze bijna altijd ingekaderd door procedurele richtsnoeren, zoals het geval is bij de Franse schikking in brede zin (de transactie), maar ook bij de eisen die worden gesteld aan compliance-programma's. De alternatieve handhavingsinstrumenten hebben in Frankrijk een eigen besluitvormingsprocedure, of maken duidelijk onderdeel uit van een andere wettelijke bevoegdheid. Denk hierbij aan de marktonderzoeken of individuele zienswijzen, die niet als losse, informele instrumenten worden beschouwd, maar als formele adviezen binnen een adviesprocedure. Alternatieve handhaving in Frankrijk lijkt derhalve sterk gekleurd te zijn door het legaliteitsbeginsel. Hoewel het label 'alternatief' doet vermoeden dat er wordt afgeweken van bestaande structuren, heeft de Franse autoriteit een manier gevonden om de alternatieve instrumenten te formaliseren. Dit komt de rechtszekerheid van bedrijven ten goede en is consistent met het strategisch doel dat de Autorité zichzelf stelde: handhaven met een focus op waarborgen. ${ }^{77}$

75. ACM, Speech van C. Fonteijn, 'Compliance is welbegrepen eigenbelang', voor de Vereniging Farmacie en Recht op 29 mei 2015.

76. Deze typering vindt niet alleen plaats op basis van de bevindingen die in dit stuk over het voetlicht worden gebracht, maar heeft een basis in het proefschrift van de auteur, Lachnit 2016.

77. De Autorité nam in de onderzochte periode 127 boetebesluiten en 105 alternatieve besluiten. Daarnaast gaf het een kleine 300 adviezen aan overheidsorganen en marktpartijen. Zie Lachnit 2016, Annex II. 
Alternatieve handhaving door de CMA

In de beschrijving van de alternatieve handhavingspraktijk van de CMA komt één aspect herhaaldelijk naar voren, namelijk dat de CMA opereert onder strikte transparantie- en motiveringsverplichtingen, om zo rechterlijke toetsing achteraf - een belangrijk aspect van een common law traditie - zo effectief mogelijk te faciliteren. Zo is de CMA verplicht te rapporteren over belangrijke momenten in haar besluitvormingsprocedure (zie bijvoorbeeld de schikking of het marktonderzoek) en zijn haar besluiten over het algemeen erg uitvoerig en volledig. Dit komt uiteraard de waarborgen voor ondernemingen ten goede, maar draagt over het algemeen niet bij aan een vlotte afwikkeling van procedures. Deze spanning staat haaks op een van de strategische doelen die de CMA voor zichzelf stelde: meer efficiënte besluitvorming. ${ }^{78}$

Daarnaast is het duidelijk dat de CMA meer discretionaire bevoegdheid geniet dan, bijvoorbeeld, de Autorité, maar er uiteindelijk toch voor koos om de alternatieve instrumenten te formaliseren in procedurele richtsnoeren. Een voorbeeld hiervan is het schikkingsinstrument, dat de CMA in de praktijk ontwikkelde op basis van de beoordelingsvrijheid bij het opleggen van een bestuurlijke boete en waarvoor na enkele jaren een 'procedural guideline' verscheen. ${ }^{79}$ Tot slot dient nog te worden opgemerkt dat de CMA zich op een opmerkelijk dubbel spoor bevindt; enerzijds is er veel aandacht voor preventieve acties (zoals voorlichting en het stimuleren van compliance), maar anderzijds wordt er op strategieniveau de nadruk gelegd op de 'robuustheid' van besluiten waarmee impliciet de mate van afschrikwekkendheid lijkt te worden bedoeld. ${ }^{80} \mathrm{Op}$ deze balans wordt hierna nog ingegaan. ${ }^{81}$

\section{ACM en alternatieve handhaving}

Van alle onderzochte mededingingsautoriteiten ligt bij ACM de nadruk bij het handhaven het meest op het bereiken van een zo groot mogelijk effect op de markt. Uit haar handhavingsstrategie komt sterk naar voren dat interventies een 'probleemoplossend karakter' dienen te hebben - hetgeen inhoudt dat het precieze handhavingsarrangement zo goed mogelijk wordt afgestemd op het marktprobleem, om te proberen dit probleem als geheel te kunnen adresseren. Vanuit die gedachte is het

78. Competition and Markets Authority, CMA 13, Vision, Values and Strategy for the CMA, January 2014.

79. Competition and Markets Authority, CMA 8, Competition Act 1998: Guidance on the CMA's investigation procedures in Competition Act 1998 cases, March 2014.

80. Deze bevinding is gebaseerd op de evaluatierapporten die het Britse Departement voor Business, Innovation and Skills opstelde ter voorbereiding op de fusie tussen de Office of Fair Trading en de Competition Commission (Department of Business Innovation and Skills, 'A Competition Regime for Growth: Consultation on Options for Reform', March 2011, en Department of Business Innovation and Skills, 'A Competition Regime for Growth: Consultation on Options for Reform - Impact Assessment', March 2012). Hierin wordt met name het gebrek aan boetebesluiten bekritiseerd. Op basis van deze bevinding lijkt het standpunt in de strategie te zijn gedaan om meer 'robuuste' handhaving na te streven. Zie Competition and Markets Authority, CMA 13, Vision, Values and Strategy for the CMA, January 2014.

81. Zie 'Balans tussen alternatieve en reguliere instrumenten' hieronder. te verklaren dat de alternatieve handhavingsinstrumenten in de beschrijving hiervoor getypeerd worden als 'nog in ontwikkeling', of 'niet geformaliseerd', omdat de precieze invulling van deze instrumenten van zaak tot zaak kan verschillen. ACM geniet, zoals gezegd, flexibiliteit onder de door de minister opgestelde beleidsregels, en heeft deze tot op heden nog niet ingevuld door nadere richtsnoeren. Dit kan leiden tot rechtsonzekerheid bij partijen, omdat zij op basis van de flexibele beleidsregels lastiger kunnen voorspellen wat zij van ACM kunnen verwachten. Los daarvan bestaat er het risico dat indien 'probleemoplossend' in voorkomende gevallen betekent 'informeel' - een gedeelte van de handhavingsactiviteiten van ACM aan rechterlijke toetsing ontsnapt. ${ }^{82}$ Hierop is - met name met betrekking tot individuele zienswijzen - in de literatuur al de nodige kritiek geweest. ${ }^{83}$

Omdat er op basis van het aantal beschikbare zaken nog geen eenduidige aanpak zichtbaar is, is het moeilijk te beoordelen hoe ACM alternatieve handhavingsinstrumenten accommodeert in de besluitvormingsprocedures. Voor sommige instrumenten worden bestaande structuren opzijgezet (zoals bijvoorbeeld het geval was bij de Vuistregels voor individuele zienswijzen), terwijl er voor andere instrumenten aan de vaste besluitvormingsprocedure wordt vastgehouden (zoals de rol van Chinese Walls in een vereenvoudigde afdoening, of schikking in brede zin). Het is - al met al - afwachten hoe de visie van ACM op toezicht en handhaving zich verder ontwikkelt in de praktijk.

\section{Alternatieve handhaving in bredere context}

De manier waarop er wordt omgegaan met alternatieve handhavingsinstrumenten zegt dus iets over de toezichtstijl van de relevante autoriteit - een toezichtstijl die op zijn beurt weer beinvloed wordt door het wettelijk kader, de eisen die aan toezichthouders worden gesteld en de waarborgen voor betrokken bedrijven. Echter, los van hoe deze wisselwerking haar weerslag heeft op de procedures voor en het gebruik van losse instrumenten, dient alternatieve handhaving ook bezien te worden in de context van het bredere handhavingsbeleid (hoe moet de verhouding tussen alternatieve en reguliere instrumenten zijn en hoe moet die keuze precies gemaakt worden?) en in de context van de relatie met verschillende

82. Overigens is dit net zo goed een risico bij de andere autoriteiten. Ook in andere landen doen toezichthouders aan informele handhaving, maar treden daar wellicht minder mee naar buiten, of plaatsen hun formele instrumentarium bewust meer op de voorgrond. Het gaat hier derhalve om een opmerking die ten aanzien van informele handhaving in het algemeen kan worden gemaakt, en niet alleen ten aanzien van de praktijk van $A C M$.

83. Zoals door A. Gerbrandy, 'Informele oordelen, de koning van Frankrijk, Khaleesi en Frank Underwood', M\&M 2015-2, p. 89-90. Maar zie ook E.S. Lachnit, 'Mededingingsautoriteiten als koorddansers: spanningen rond individuele zienswijzen', SEW 2016-12, p. 523-531. 
stakeholders bij toezicht en handhaving (zoals de minister, de onder toezicht gestelden en de rechter). ${ }^{84} \mathrm{De}$ opmerkingen die dienaangaande gemaakt worden, beperken zich niet tot het mededingingstoezicht, maar zijn van toepassing op alle toezichthouders voor zover zij gebruikmaken van alternatieve handhaving.

\section{Balans tussen reguliere en alternatieve instrumenten}

Bij de typering van de nationale autoriteiten, maar ook bij bespreking van de verschillende instrumenten, blijkt dat alternatieve handhaving vaak wordt afgezet tegen 'reguliere' handhaving. Er dient een balans te zijn tussen beide, omdat de karakteristieken van de verschillende instrumenten als complementair kunnen worden gezien. Hoewel alternatieve handhaving flexibel is en (vaak) sneller tot resultaten kan leiden, valt of staat het succes van de instrumenten met de medewerking van de betrokken bedrijven. Die medewerking zal in veel gevallen niet worden verleend als er geen geloofwaardige dreiging van de toezichthouder uitgaat. ${ }^{85}$ Er dient dus van tijd tot tijd ook streng te worden opgetreden; alternatieve handhaving en reguliere handhavingsinstrumenten dienen in balans te zijn.

$\mathrm{Er}$ is nog een andere reden om een balans tussen alternatieve en reguliere instrumenten na te streven. Zoals blijkt uit de korte beschrijving hierboven zet de toepassing van enkele van de alternatieve handhavingsinstrumenten de rechtswaarborgen voor partijen onder druk. Wanneer er meer gebruik wordt gemaakt van alternatieve handhaving verplaatst die spanning zich van het individuele zaaksniveau naar beleidsniveau en kan er - op langere termijn - sprake zijn van een systematisch legaliteitsprobleem. Om de balans tussen alternatieve en reguliere instrumenten te bewerkstelligen moeten toezichthouders heldere uitgangspunten formuleren voor de toepassing van elk type instrumenten. Zeker wanneer er geen duidelijke richtsnoeren zijn over de precieze toepassing, kunnen dergelijke uitgangspunten duidelijkheid bieden aan marktpartijen, en de gepercipieerde coherentie en legitimiteit verhogen. Hierbij kan als uitgangspunt worden genomen dat alternatieve handhavingsinstrumenten beter niet toegepast kunnen worden wanneer er terugkerende nieuwe en opgeloste vragen zijn, wanneer deterrence in een bepaalde sector verhoogd moet worden, of wanneer bedrijven zich onwelwillend opstellen. ${ }^{86}$

\section{Alternatieve handhaving en toezichtsrelaties}

Een toezichthouder opereert niet in een vacuüm. De keuzes die gemaakt worden met betrekking tot handhaving kunnen worden beinvloed door andere spelers in het veld, maar kunnen hen ook beinvloeden. Hierbij kan, op de eerste plaats, de vraag worden gesteld hoe vrij mededingingsautoriteiten eigenlijk zijn bij het maken van keuzes voor bepaalde handhavingsinstrumenten. Heel kort door de bocht: boetes leveren geld op, terwijl informele interventies of preventieve acties geld kosten. ${ }^{87}$ Uit de alternatieve handhavingspraktijk binnen het mededingingstoezicht blijkt dat de verantwoordelijke ministers soms invloed hebben op die beslissing (denk bijvoorbeeld aan de strategische focus op meer 'robuuste' besluiten in het Verenigd Koninkrijk), maar over het algemeen maken de mededingingsautoriteiten hierin zelfstandige keuzes. De spanning tussen effecten en kosten is uiteraard niet specifiek voor het mededingingsrecht; in zijn algemeenheid geldt dat toezichthouders onder druk staan om zo veel mogelijk resultaat te behalen met zo min mogelijk middelen. ${ }^{88} \mathrm{Er}$ zal derhalve een balans moeten worden gezocht tussen kosteneffectiviteit en de uitwerking van de interventie op de markt. Idealiter zou de toezichthouder in dat opzicht moeten kiezen voor het middel dat die balans het beste treft en zich niet enkel laten leiden door kostenoverwegingen.

Een tweede punt dat toezichthouders zich moeten realiseren bij het toepassen van alternatieve handhaving, is dat juist de relatie met de betrokken bedrijven een risico vormt. Met betrekking tot de onderhandelingsfase in een schikking in brede zin werd al opgemerkt dat er een risico op regulatory capture bestond, maar dit is evenzogoed het geval bij meer informele afdoeningen, bij het bespreken van aanbevelingen aan de markt of bij het monitoren van een compliance-programma. Hoe intensiever de samenwerking is, hoe groter het risico op capture. ${ }^{89}$ Een toezichthouder dient hiervoor te waken en geschikte procedurele waarborgen in te bouwen om dit te voorkomen, zoals de scheiding tussen onderzoek en besluitvorming of een scheiding tussen monitoring en onderzoek. Daarnaast kan er, wanneer er gebruik wordt gemaakt van een informeel advies (zoals een individuele zienswijze) - zoals hierboven betoogd - bij adviezen van groter maatschappelijk belang gebruik worden gemaakt van een consultatie om de analyse van de autoriteit te toetsen aan de verwachtingen van het publiek. Verder is de balans tussen alternatieve en reguliere handhaving een belangrijke voorwaarde om capture te kunnen voorkomen.

87. Aan de andere kant: boeteprocedures zijn langdurige en dure procedures, terwijl informele interventie snel resultaat kan bewerkstelligen en preventieve actie verdere handhaving zelfs voorkomt.

88. Zie in dit kader bijvoorbeeld een eerdere bijdrage in dit tijdschrift: A.T. Ottow, 'De toezicht Bermudadriehoek', TVT 2011, afl. 4, p. 48-50.

89. Zie voor een uitgebreide bespreking van de waarde van onafhankelijkheid (en het voorkomen van capture) M. Aelen, Beginselen van Goed Markttoezicht, Den Haag: Boom juridische uitgevers 2014 of A.T. Ottow, Market and Competition Authorities: Good Agency Principles, Oxford: Oxford University Press 2015.
4. Er zijn uiteraard meer aspecten te benoemen (en ook benoemd in het Dit is de aanname achter literatuur over de relatie tussen deterrence en compliance, hoewel er ook andere motieven aan regelnaleving ten grondslag kunnen liggen. Zie in dit kader bijvoorbeeld W.P.J. Wils, 'Optimal Antitrust Fines', World Competition 2006, vol. 29, nr. 2, die refereert aan J. Adanaes, 'The moral or educative influence of criminal law', Journal of Social Issues 1971, vol. 27, nr. 17.

86. Deze vereisten zijn afgeleid uit het proefschrift van de auteur, waarin de herkomst ervan nader uitgewerkt wordt. Zie Lachnit 2016, hfdst. 9. 
Tot slot is er nog de relatie tussen de toezichthouder en de rechter die door het gebruik van alternatieve handhavingsinstrumenten onder druk kan komen te staan. Dit kan komen doordat bedrijven zo betrokken zijn bij de procedurele stappen dat bezwaar en beroep onwaarschijnlijk is (zoals in een schikking in brede zin), maar ook omdat er bij de toepassing van sommige instrumenten geen appellabel besluit wordt genomen (individuele zienswijze of marktonderzoek in brede zin). Dit kan zorgelijk zijn, omdat een belangrijk deel van de ontwikkeling van het recht plaatsvindt bij de rechter, maar ook omdat er in afwezigheid van rechterlijke toetsing altijd de mogelijkheid bestaat dat de toezichthouder buiten de gestelde juridische kaders handhaaft (denk, bijvoorbeeld, aan de risico's van over-commitment met betrekking tot marktonderzoek). Vooral dit laatste punt leidt tot discussie, omdat het aansluit bij de vraag hoe breed de taakomschrijving van toezichthouders eigenlijk moet worden opgevat. ${ }^{90}$ Deze spanning onderschrijft derhalve de noodzaak van een gebalanceerd handhavingsbeleid met duidelijke uitgangspunten. Om deze spanning te kunnen verlichten zou een dergelijk beleid in ieder geval aandacht moeten besteden aan de situaties waarin de toepassing van een handhavingsinstrument geschikt wordt geacht. ${ }^{91}$

\section{Afsluitende opmerkingen}

Deze bijdrage had tot doel om te illustreren wat de gevolgen kunnen zijn van een brede toepassing van alternatieve handhavingsinstrumenten vanuit het perspectief van toezicht. Zoals blijkt uit de bespreking van de handhavingspraktijk van ACM, de CMA en de Autorité zorgt de toepassing van alternatieve handhavingsinstrumenten voor een veranderde verhouding tussen bedrijven en toezichthouder, en tussen toezichthouder en rechter. Daarnaast geven alternatieve handhavingsinstrumenten vorm aan een nieuwe vorm van toezicht (vaker informeel, meer horizontaal, compliance-gericht, proactief, breed inzetbaar of een combinatie hiervan), waarbij opvalt dat de nationaalrechtelijke context waarin de instrumenten gebruikt worden erg bepalend is voor de manier waarop zij in de praktijk worden toegepast.

Op basis van de (korte) uiteenzetting hierboven, zijn de volgende aanbevelingen gedaan om alternatieve handhavingsinstrumenten te integreren in een handhavingsstrategie: ${ }^{92}$

- Om een geloofwaardige dreiging te blijven vormen, maar ook om een legaliteitsprobleem op strategisch niveau te voorkomen dient er balans te zijn tussen reguliere en alternatieve handhavingsinstrumenten. Deze balans kan worden nagestreefd door heldere uitgangspunten te formuleren voor de toepassing van elk type instrumenten.

- Voor de toepassing (en monitoring) van alternatieve handhavingsinstrumenten dient te worden bezien of er institutionele waarborgen nodig zijn om capture te voorkomen.

- Wanneer een interventie een groot maatschappelijk belang raakt, maar er - door de toepassing van een alternatief handhavingsinstrument - geen rechterlijke toetsing plaatsvindt, kan een publieke consultatie een indicatie geven van de gepercipieerde legitimiteit.

Deze aanbevelingen raken - hoewel zeer beknopt weergegeven - de drie onderdelen waaraan in deze bijdrage aandacht is besteed: de balans tussen alternatieve en reguliere handhavingsinstrumenten en hun plaats in een handhavingsstrategie, de inrichting van de toezichthouder zelf en de positionering van de toezichthouder naar buiten toe. Voor de Nederlandse praktijk betekent dit concreet dat er wellicht meer handen en voeten kan worden gegeven aan wat 'probleemoplossend toezicht' in het mededingingstoezicht inhoudt. Hierbij kan er worden gedacht aan het formuleren van uitgangspunten bij de toepassing van verschillende alternatieve handhavingsinstrumenten, zoals de vereenvoudigde afdoening en de individuele zienswijze. Dit geeft niet alleen bedrijven meer zekerheid, maar biedt ook houvast bij het maken van een keuze voor de meest geschikte interventie.

Door het gebruik van alternatieve handhavingsinstrumenten neemt het belang van een uitgebalanceerd handhavingsbeleid alleen maar toe; een beleid dat niet alleen het effect van de interventie in ogenschouw neemt, maar ook oog heeft voor de legitimiteit van de autoriteit zelf (en haar gehele beleid), de interne en externe beslissingsstructuren en invloedsporen, en de ontwikkeling van het recht zelf. Deze bijdrage laat echter ook zien dat toezichthouders heel inventief kunnen zijn in het omgaan met deze uitdagingen, ondanks de politieke en praktische spanningen waar zij soms onder opereren. Dit laat zien dat er, ondanks verschillen in juridisch kader, missie en strategie, welhaast altijd ruimte kan worden gemaakt voor alternatieve handhaving, ook buiten het mededingingstoezicht.

90. Mogen toezichthouders optreden wanneer bepaald gedrag schadelijk is, maar strikt genomen niet verboden, of mogen zij alleen optreden als bepaald gedrag verboden is - ongeacht de vraag of het schadelijk is of niet. Zie in dit kader uitgebreider M. Sparrow, The Regulatory Craft; Controlling Risks, Solving Problems and Managing Compliance, Washington: The Brookings Institution 2000.

91. Zie hiervoor, bijvoorbeeld, de suggestie die hierboven is gedaan met betrekking tot de toepassing van marktonderzoeken ('Marktonderzoek in brede zin').

92. Uiteraard vinden deze aanbevelingen hun grondslag in de uitgebreidere analyse van de handhavingspraktijk van de drie onderzochte mededingingsautoriteiten, zoals uitgevoerd in het proefschrift van de auteur. 